\title{
Discussion of some taxonomy issues of species of the genus Iris L. based on biomorphological and karyological characteristics
}

\author{
Elvira Aukhadieva, ${ }^{1, *}$, Nadezhda Kalashnik $^{2}$, and Airat Ishbirdin $^{3}$ \\ ${ }^{1}$ Ufa Research Institute of Occupational Health and Human Ecology, 450106 Ufa, Russian Federation \\ ${ }^{2}$ Ufa Institute of Biology-Subdivision of the Ufa Federal Research Center of the Russian Academy of \\ Sciences, 450054 Ufa, Russian Federation \\ ${ }^{3}$ Bashkir State University, 450076 Ufa, Russian Federation
}

\begin{abstract}
A comparative analysis of ten taxa of the genus Iris was carried out based on biomorphological and karyological characteristics. The assessment of morphological variability structure allowed to identify taxonomic indicators common to the analyzed species and characterized by relatively low common and consistent variability: length and width of the outer perianth lobes, length and width of the inner perianth lobes, length of the stamen filament, anther and pistil, width of the fruit, as well as length and width of the seed. Based on the constructed phylogenetic relationships based on the identified taxonomic features, the studied species were grouped into conditional groups: 1. I. carthaliniae, I. halophila, I. spuria; 2. I. lactea; 3. I. pseudacorus, I. setosa; 4. I. sibirica, I. sanguinea; 5. I. graminea; 6. I. pumila, which is also consistent with chromosome numbers found by us in somatic tissue.
\end{abstract}

\section{Introduction}

The genus Iris L. is the largest and most complex genus of the family Iridaceae and includes, according to various authors, from 200 to 400 species (according to the database The Plant List - 362 [1]) and more than 35 thousand varieties [2]. Its composition is periodically supplemented with new described species [3-5]. Despite the fact that the genus Iris has been studied extensively, there is no single system of it, and there are different opinions about its scope. The classification schemes are based on the comparison of anatomical-morphological and cytogenetic features [6-9], as well as on the results of molecular-biological and biochemical studies [10-12]. When compiling keys for determining the species of the genus Iris [13-16], the authors consider such traits as the color and size of the perianth lobes, the length of the ovary, the presence or absence of a barbule of multicellular hairs in the outer perianth lobes, the number of flowers on the peduncle, the height of the peduncle, the length and width of the leaves, the shape and nature of seed case opening, the ratio of seed case length to width, the shape of seeds and

\footnotetext{
${ }^{*}$ Corresponding autor: phytoufa@yandex.ru
} 
the nature of seed peel structure, the color of the roots, the nature of branching and the thickness of the rhizome, the flowering time, and some others.

There are publications on the use of morphological variability structure assessment in biology for the classification of morphological features of some plant and animal species by the ratio of common and consistent variability. The authors distinguish 4 groups of indicators: ecological and biological system, biological, genetic (taxonomic) and environmental indicators. Thus, such traits were found for Helianthus annuus [17], Cephalanthera rubra [18], etc. For representatives of the genus Iris, such works have not been identified in the literature.

In order to identify the taxonomically significant morphological features of the generative and vegetative spheres of the species of the genus Iris and their applicability to the phylogenetic relationship of the numerical classification, the structure of the morphological variability of plants of 10 species was evaluated. To identify taxonomic indicators, we considered the traits most accessible for study (height of the generative shoot, length and width of the leaf, length and width of the perianth lobes, length of the stamen thread, anther and pistil, length and width of the fruit, length and width of the seed). When discussing the taxonomy of representatives of the genus Iris, the results of a study of a set of chromosomes in somatic tissue are used.

\section{Materials and methods}

The objects of research were wild representatives of species of the genus Iris, introduced at the collection site of the South Ural Botanical Garden-Institute of the Ufa Federal Research Center of the Russian Academy of Sciences: I. pseudacorus L., I. sibirica L., I. sanguine Doon., I. setosa Pall. ex Link, I. carthaliniae Fomin., I. halophila Pall., I. graminea L., I.spuria L., I. pumila L., I. lactea Pall. Morphometric parameters were taken into account in 25 middle-aged generative plants of each species being in the flowering phase [19]. Morphometric parameters of shoots, flowers and fruits were measured using a ruler, and seeds were measured using a Levenhuk DTX 90 microscope. Karyological studies were carried out on the meristematic tissue of the roots using the method of preparation of timepressed preparations [20], which was adapted experimentally in relation to the species of the genus Iris. The calculation of the main statistical characteristics was performed according to the method of G.N. Zaitsev [21] using MS Excel and Statistica programs.

In connection with the identification of a large number of controversial issues in the taxonomy of the genus Iris L., in this paper we focused on the classifications of three main authors: B. Mathew [22], G.I. Rodionenko [6, 23] and V.M. Doronkin [24].

\section{Results and discussion}

The results of karyological studies [25] showed that the somatic number of chromosomes in the studied species is $2 \mathrm{n}=28$ (I. sibirica, I. sanguinea), $2 \mathrm{n}=30$ (I. pumila), $2 \mathrm{n}=34$ ( . pseudacorus, I. graminea, I. setosa), 2n=40 (I. lactea) and $2 \mathrm{n}=44$ (I. carthaliniae, $I$. halophila, I. spuria). From the proposed karyotype formulas, it follows that the species belonging to a particular subgenus are generally characterized by the same level of ploidy. Thus, all the studied representatives of the subgenera Limniris, as well as the species $I$. pumila (subgenus Iris) and I. graminea (subgenus Xyridion), are probably tetraploids, and the species of the subgenera Xyridion (excluding I. graminea) and I. lactea (from the subgenus Limniris according to G.I. Rodionenko [6] or the subgenus Eremiris according to V.M. Doronkin [24] - hexaploids. 
Monograph of the genus G.I. Rodionenko, conducting a revision of the system of the genus Iris, in his later works recognizes the independence of several subgenera of Iris and raises them to the rank of genus: genus Xyridion (Tausch) Fourr. [26], the genus Limniris (Tausch) Reichenb. [27] and the genus Eremiris (Spach) Rodionenko [28]. Thus, according to the author's later classification, the studied species are representatives of different genera: the genus Limniris Spachem. Rodion. includes L. pseudacorus, L. setosa, L. sibirica, L. sanguinea, the genus Xyridion Spachem. Rodion. includes $X$. carthaliniae, $X$. halophila, $X$. spuria, $X$. graminea, the genus Iris L. includes I. pumila, the genus Eremiris Spach. includes E. lactea. The systematic position of the studied species according to the classification of G.I. Rodionenko [23] is presented in Table 1.

Table 1. The systematic position of the studied species according to the classification of G.I.

Rodionenko [23]

\begin{tabular}{|c|c|c|c|}
\hline Species & $\begin{array}{l}\text { Number of } \\
\text { chromosomes } \\
(2 \mathrm{n})\end{array}$ & $\begin{array}{l}\text { Conditional } \\
\text { group number }\end{array}$ & Systematic position \\
\hline Xyridion spurium (Iris spuria) & 44 & \multirow{3}{*}{1} & \multirow{3}{*}{$\begin{array}{l}\text { Genus Xyridion } \\
\text { Section Xyridion } \\
\text { Series Xyridion }\end{array}$} \\
\hline Xyridion halophilum (Iris halophila) & 44 & & \\
\hline $\begin{array}{lll}\begin{array}{l}\text { Xyridion } \\
\text { carthaliniae) }\end{array} & \text { carthalinium } & \text { (Iris } \\
\end{array}$ & 44 & & \\
\hline Xyridion graminea (Iris graminea) & 34 & 2 & $\begin{array}{l}\text { Genus Xyridion } \\
\text { Section Xyridion } \\
\text { Series Graminea }\end{array}$ \\
\hline Eremiris lactea (Iris lactea) & 40 & 3 & Genus Eremiris \\
\hline Limniris sibirica (Iris sibirica) & 28 & \multirow[t]{2}{*}{4} & \multirow[t]{2}{*}{$\begin{array}{l}\text { Genus Limniris } \\
\text { Subgenus Limniris } \\
\text { Section Limniris } \\
\text { Series Limniris }\end{array}$} \\
\hline Limniris sanguinea (Iris sanguinea) & 28 & & \\
\hline $\begin{array}{lll}\text { Limniris } & \text { pseudacorus } & \text { (Iris } \\
\text { pseudacorus) }\end{array}$ & 34 & \multirow[t]{2}{*}{5} & \multirow{2}{*}{$\begin{array}{l}\text { Genus Limniris } \\
\text { Subgenus Limniris } \\
\text { Section Laevigatae }\end{array}$} \\
\hline Limniris setosa (Iris setosa) & 34 & & \\
\hline Iris pumila & 30 & 6 & $\begin{array}{l}\text { Genus Iris } \\
\text { Subgenus Iris } \\
\text { Section Pumilae }\end{array}$ \\
\hline
\end{tabular}

When comparing the chromosome numbers of the studied species with the new system of genera according to the classification of G.I. Rodionenko [23] it is seen that they consistent with it. Thus, I. carthaliniae, I. halophila, I. spuria with the number of chromosomes $2 \mathrm{n}=44$ make up one group, I. graminea $(2 \mathrm{n}=34)-$ the second, I. lactea $(2 \mathrm{n}=40)-$ the third, I. sibirica, I. sanguinea $(2 \mathrm{n}=28)$ - the fourth, I. pseudacorus, I. setosa $(2 \mathrm{n}=34)$ - the fifth, I. pumila $(2 \mathrm{n}=30)$ - the sixth conditional groups (Table 1). I. graminea is included in the genus Xyridion, as well as I. carthaliniae, I. halophila, I. spuria, but, unlike them, in a different series (Graminea). In turn, I. sibirica, I. sanguinea, as well as I. pseudacorus, I. setosa are included in the genus Limniris, subgenus Limniris, but represent different sections (Limniris and Laevigatae, respectively).

Morphological data were analyzed for 2009-2011 years of research. The biometric indicators were compared for the statistical significance of their differences over the years. The values of the studied indicators were checked for the normality of distribution according to the Kolmogorov-Smirnov criterion. To compare independent samples with a normal distribution, a one-factor analysis of variance was used, and for samples that do not obey the law of normal distribution, the Kruskal-Wallis test was used. The analysis showed that for all the studied parameters, the difference is insignificant at the significance level $\mathrm{W}=5 \%$, which allows to assess the structure of the variability of morphological features and classify them into groups. Graphs on the structure of morphological trait variability were compiled for all 10 taxa, for 3 years of research. Figure 1 shows the variability 
structure for I. sibirica as an example. Among the studied characteristics for all species, ecological and biological system, biological and genetic (taxonomic) indicators are identified (Table 2).

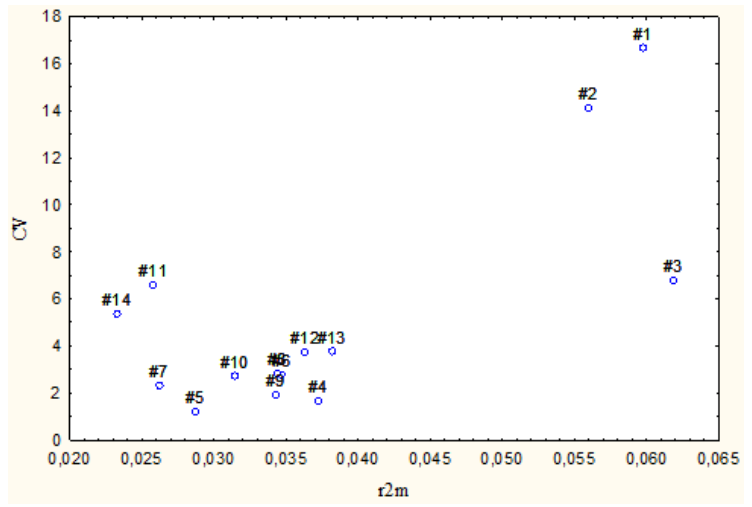

Fig. 1. Structure of variability of I. sibirica morphological features

Note: on the abscissa axis - consistent variability $\left(\mathrm{r}^{2} \mathrm{~m}\right)$, on the ordinate axis - common variability (CV, \%). Symbols: 1 - height of the generative shoot, 2 - length of the leaf, 3 - width of the leaf, 4 length of the outer lobes of the perianth, 5 - width of the outer lobes of the perianth, 6 - length of the inner lobes of the perianth, 7 - width of the inner lobes of the perianth, 8 - length of the staminate filament, 9 - length of the anther, 10 - length of the pistil, 11 - length of the fruit, 12 - width of the fruit, 13 - length of the seed, 14 - width of the seed.

Table 2. Classification of characteristics of species of the genus Iris by the structure of variability

\begin{tabular}{|c|c|c|c|c|c|c|c|c|c|c|c|c|c|c|}
\hline \multirow[b]{2}{*}{ Species } & \multicolumn{14}{|c|}{ Trait } \\
\hline & 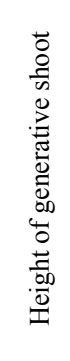 & 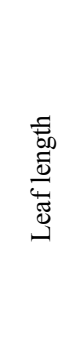 & 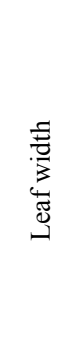 & 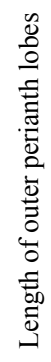 & 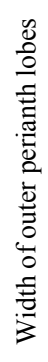 & 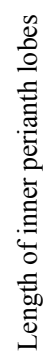 & 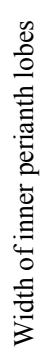 & 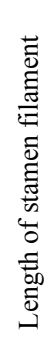 & 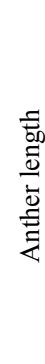 & 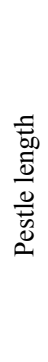 & 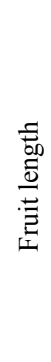 & 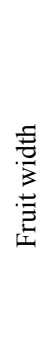 & $\begin{array}{l}\vec{\Xi} \\
\overrightarrow{0} \\
\vec{\Xi} \\
\vec{\Xi} \\
\vec{D} \\
\tilde{D}\end{array}$ & 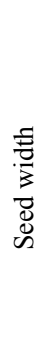 \\
\hline $\begin{array}{l}\text { I. } \\
\text { carthaliniae }\end{array}$ & E-B & E-B & E-B & $\mathrm{T}$ & $\mathrm{T}$ & $\mathrm{T}$ & $\mathrm{T}$ & $\mathrm{T}$ & $\mathrm{T}$ & $\mathrm{T}$ & B & $\mathrm{T}$ & $\mathrm{T}$ & $\mathrm{T}$ \\
\hline I. graminea & E-B & $\mathrm{B}$ & $\mathrm{B}$ & $\mathrm{T}$ & $\mathrm{T}$ & $\mathrm{T}$ & $\mathrm{T}$ & $\mathrm{T}$ & $\mathrm{T}$ & $\mathrm{T}$ & $\mathrm{T}$ & $\mathrm{T}$ & $\mathrm{T}$ & $\mathrm{T}$ \\
\hline I. halophila & E-B & E-B & $\mathrm{B}$ & $\mathrm{T}$ & $\mathrm{T}$ & $\mathrm{T}$ & $\mathrm{T}$ & $\mathrm{T}$ & $\mathrm{T}$ & $\mathrm{T}$ & $\mathrm{B}$ & $\mathrm{T}$ & $\mathrm{T}$ & $\mathrm{T}$ \\
\hline I. lactea & $\mathrm{B}$ & E-B & $\mathrm{T}$ & $\mathrm{T}$ & $\mathrm{T}$ & $\mathrm{T}$ & $\mathrm{T}$ & $\mathrm{T}$ & $\mathrm{T}$ & $\mathrm{T}$ & $\mathrm{T}$ & $\mathrm{T}$ & $\mathrm{T}$ & $\mathrm{T}$ \\
\hline $\begin{array}{l}\text { I. } \\
\text { pseudacorus }\end{array}$ & E-B & E-B & B & $\mathrm{T}$ & $\mathrm{T}$ & $\mathrm{T}$ & $\mathrm{T}$ & $\mathrm{T}$ & $\mathrm{T}$ & $\mathrm{T}$ & B & $\mathrm{T}$ & $\mathrm{T}$ & $\mathrm{T}$ \\
\hline I. pumila & E-B & E-B & $\mathrm{T}$ & $\mathrm{T}$ & $\mathrm{T}$ & $\mathrm{T}$ & $\mathrm{T}$ & $\mathrm{T}$ & $\mathrm{T}$ & $\mathrm{T}$ & $\mathrm{T}$ & $\mathrm{T}$ & $\mathrm{T}$ & $\mathrm{T}$ \\
\hline I. sanguinea & E-B & $\mathrm{B}$ & $\mathrm{T}$ & $\mathrm{T}$ & $\mathrm{T}$ & $\mathrm{T}$ & $\mathrm{T}$ & $\mathrm{T}$ & $\mathrm{T}$ & $\mathrm{T}$ & $\mathrm{T}$ & $\mathrm{T}$ & $\mathrm{T}$ & $\mathrm{T}$ \\
\hline I. setosa & E-B & E-B & $\mathrm{T}$ & $\mathrm{T}$ & $\mathrm{T}$ & $\mathrm{T}$ & $\mathrm{T}$ & $\mathrm{T}$ & $\mathrm{T}$ & $\mathrm{T}$ & $\mathrm{T}$ & $\mathrm{T}$ & $\mathrm{T}$ & $\mathrm{T}$ \\
\hline I. sibirica & E-B & E-B & $\mathrm{B}$ & $\mathrm{T}$ & $\mathrm{T}$ & $\mathrm{T}$ & $\mathrm{T}$ & $\mathrm{T}$ & $\mathrm{T}$ & $\mathrm{T}$ & $\mathrm{T}$ & $\mathrm{T}$ & $\mathrm{T}$ & $\mathrm{T}$ \\
\hline I. spuria & E-B & E-B & E-B & $\mathrm{T}$ & $\mathrm{T}$ & $\mathrm{T}$ & $\mathrm{T}$ & $\mathrm{T}$ & $\mathrm{T}$ & $\mathrm{T}$ & $\mathrm{B}$ & $\mathrm{T}$ & $\mathrm{T}$ & $\mathrm{T}$ \\
\hline
\end{tabular}

Symbols: E-B - ecological and biological system indicators, B - biological indicators, $\mathrm{T}$ - taxonomic indicators. 
No environmental indicators were detected. Thus, such indicators as the height of the generative shoot in I. carthaliniae, I. graminea, I. halophila, I. pseudacorus, I. pumila, I. sanguinea, I. setosa, I. sibirica, I. spuria, the leaf length in I. carthaliniae, I. halophila, I. lactea, I. pumila, I. pseudacorus, I. setosa, I. sibirica, I. spuria, leaf width in I. carthaliniae, I. spuria, characterized by a low and medium level of overall variability $(\mathrm{CV}=8.1-20.2 \%)$, are assigned to the group of ecological and biological system indicators. Their variability is closely related to environmental conditions, but at the same time, these changes affect the morphology of the entire organism. In the other species, the above indicators are mainly assigned to the group of biological indicators that do not depend much on environmental conditions, determine the habit of the plant and have a high determinacy with a slight variation $(\mathrm{CV}=5.9-8.8 \%)$. The indicator of leaf width in only 4 species (I. lactea, I. pumila, I. sanguinea, I. setosa) with a very low and low level of overall variability (4.1-8.6\%) represents a group of taxonomic indicators. Thus, the indicators of the generative shoot height, the length and width of the leaf in the studied species have the least informative value when considering them as a taxonomic feature.

All the studied parameters of the flower (length and width of the outer lobes, length and width of the inner lobes of the perianth, length of the stamen thread, anther and pistil), characterized by very low levels of general $(\mathrm{CV}=0.8-6.0 \%)$ and consistent $\left(\mathrm{r}_{\mathrm{m}}{ }_{\mathrm{m}}=0.005\right.$ 0.078 ) variability, are assigned to the group of taxonomic indicators. The inner lobes of the perianth in species of the genus Iris perform a signaling function and are most often characterized by a brighter color or, conversely, by complete or partial reduction, as in $I$. setosa and I. pseudacorus, and in this case the function of attracting pollinating insects is assumed by the outer lobes. In addition, the outer lobes of the perianth of all species of the genus, characterized by a rounded and concave surface, perform an aerodrome function [29]. It can be assumed that the lower the determination of the parts of the flower (the genetically determined autonomization of the trait in the morphological structure), the greater the specialization to the pollinator determined by the morphological attraction. Thus, all the studied parameters of the flower can be recommended as taxonomic indicators.

Indicators of fruits and seeds of the studied species (fruit width, length and width of the seed), characterized by very low values of the coefficient of variation $(\mathrm{CV}=0.6-7.0 \%)$ and consistent variability $\left(\mathrm{r}_{\mathrm{m}}^{2}=0.019-0.040\right)$, based on the obtained graphs on the structure of variability, represent a group of taxonomic indicators. Only 6 species (I. graminea, I. pumila, I. lactea, I. sanguinea, I. setosa, I. sibirica), with relatively low common ( $\mathrm{CV}=3.1$ $8.7 \%)$ and consistent $\left(\mathrm{r}_{\mathrm{m}}^{2}=0.019-0.040\right)$ variability are classified as taxonomic indicators. In other species, this trait is a biological indicator, so we cannot recommend it as a diagnostic indicator when determining species.

Thus, 10 taxonomic indicators were identified that are common to the analyzed taxa and are characterized by relatively low overall and consistent variability: the length and width of the outer perianth lobes, the length and width of the inner perianth lobes, the length of the stamen thread, anther and pistil, the width of the fruit, as well as the length and width of the seed. 


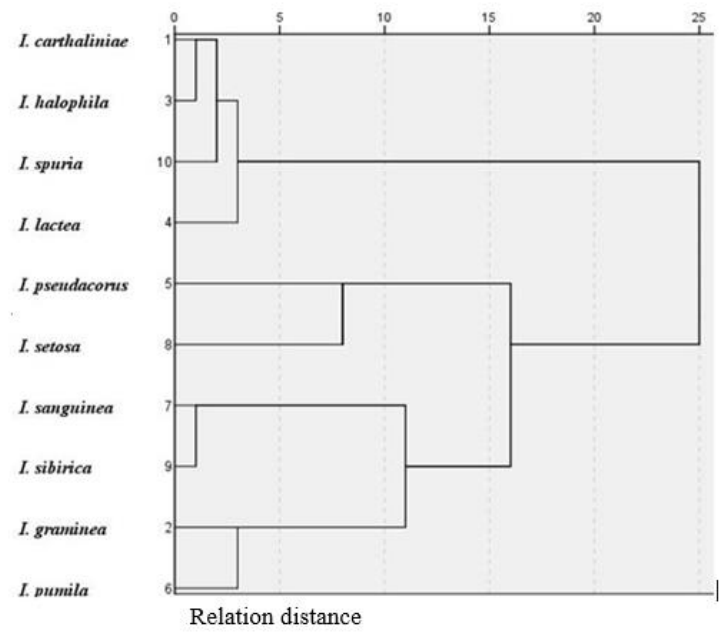

Fig. 2. Dendrogram of differences-similarities of species of the genus Iris by identified taxonomic indicators

To establish the relationship of the studied representatives of the genus Iris, a cluster analysis (hierarchical classification, the Ward method) was carried out and a dendrogram of the difference-similarity of the species was constructed according to the identified diagnostic markers. As can be seen from the dendrogram (Fig. 2), the species according to these indicators at a distance of 25.0 are divided into two large clusters. The first cluster includes the species I. carthaliniae, I. halophila, I. spuria (subgenus Xyridion [6] or Limniris [22]), as well as I. lactea (subgenus Limniris [6, 22] or Eremiris [24]). The second cluster includes the species I. pseudacorus, I. setosa, I. sanguinea, I. sibirica (subgenus Limniris), as well as I. graminea (subgenus Xyridion or Limniris) and I. pumila (subgenus Iris). Large clusters are divided into smaller clusters. The closest relationship is found between the species I. sarthaliniae and I. halophila, as well as between the species $I$. sibirica and I. sanguinea. Their relationship is also evident in plant habitus.

The views on the dendrogram can be grouped into conditional groups: 1. I. carthaliniae, I. halophila, I. spuria; 2. I. lactea; 3. I. pseudacorus, I. setosa; 4. I.sibirica, I. sanguinea; 5. I. graminea; 6. I. pumila. These conditional groups are also consistent with the number of chromosomes in somatic tissue and the system of genera of G.I. Rodionenko [23]. Based on the relative position of the species on the dendrogram according to the identified taxonomic indicators, it can be concluded that the subgenus Limniris is the most heterogeneous in composition, which was confirmed by other authors [30,24]. The materials of the work can be a good tool for solving breeding problems, because the correct selection of parental forms for hybridization directly depends on knowledge about the degree of their relationship and the characteristics of the karyotype.

\section{Conclusions}

1. Based on the assessment of the structure of morphological variability of representatives of the genus Iris, 10 taxonomic indicators were identified.

2. The construction of phylogenetic relationships of the studied species according to the identified taxonomic indicators made it possible to combine them into conditional groups that also agree with the numbers of chromosomes in somatic tissue. 


\section{References}

1. The Plant List (2021) http://www.theplantlist.org

2. G.I. Rodionenko, Irises, 159 (1988)

3. Y.T. Zhao, Acta Phytotaxonomica Sinica, 30(2), 181 (1992)

4. B. Mitic, Phyton, 42(2), 305 (2002)

5. N.B. Alekseeva, Turczaninowia, 14(1), 59 (2011)

6. G.I. Rodionenko, Genus Iris - Iris L., 216 (1961)

7. V.M. Doronkin, Botanical Journal, 69(5), 683 (1984)

8. B. Mathew, Oregon Timber Press, 215 (1990)

9. I.F. Makarevich, Turczaninowia, 4(4), 80 (2001)

10. G. Reeves, Amer. J. Botany, 84(6), 109 (1997)

11. A.S. Antonov, Pl. Syst. Evol., 161, 155 (1988)

12. O.V. Dorogina, Turczaninowia, 15(4), 76 (2012)

13. N.B. Alekseeva, Turczaninowia, 11(2), 5 (2008)

14. Yu.E. Alekseyev, E.B. Alekseev, K.K. Gabbasov et al, Onocleaceae-Fumariaceae, 316 (1988)

15. P.F. Mayevsky, Flora of the middle zone of the European part of Russia, 600 (2006)

16. N.A. Avrorin. Ornamental herbaceous plants, 2, 458 (1977)

17. N.S. Rostova, Correlations: structure and variability, 308 (2002)

18. A.R. Ishbirdin, M.M. Ishmuratova, T.V. Zhirnova, Bulletin of the Nizhny Novgorod University n.a. N.I. Lobachevsky, 1, 85 (2005)

19. V.N. Golubev, Proceedings of th Central-Chernozem Reservation n.a. V.V. Alyokhina, 7, 602 (1962)

20. Z.P. Pausheva, Practicum on Plant Cytology, 304 (1980)

21. G.N. Zaitsev, Mathematical Statistics in Experimental Botany, 424 (1984)

22. B. Mathew, Oregon Timber Press, 326(1989)

23. G.I. Rodionenko, Penetrate into the secrets of nature (My fate - irises), 260 (2013)

24. V.M. Doronkin, The role of botanical gardens in preserving the biodiversity of the plant world of Asian Russia: present and future, 101 (2006)

25. E.A. Muratova, N.A. Kalashnik, L.N. Mironova, Bulletin of the Ufa Scientific Center of the Russian Academy of Sciences, 3, 71 (2013)

26. G.I. Rodionenko, Botanical Magazine, 91(11), 1707 (2006)

27. G.I. Rodionenko, Botanical Magazine, 92(4), 547 (2007)

28. G.I. Rodionenko, Botanical Magazine, 90(1), 55 (2005)

29. G.I. Rodionenko, Botanical Magazine, 42(6), 867 (1957)

30. V.M. Doronkin, K.S. Baykov, Turczaninowia, 7(2), 45 (2004) 